\title{
TANGGUNGJAWAB BLU TRANSJAKARTA TERHADAP PIHAK KETIGA DALAM HAL TERJADI KECELAKAAN MENURUT UU NO. 22 TAHUN 2009 TENTANG LALU LINTAS DAN ANGKUTAN JALAN
}

\author{
Elfrida R. Gultom \\ Fakultas Hukum Universitas Trisakti Jakarta \\ E-mail: elfrida.r.goeltom@gmail.com
}

\begin{abstract}
The objective of Busway development is to provide transportation services faster, safer, comfortable, and affordable for people in Jakarta. Ticket prices are subsidized by the local government busway. Busway given special line, however could not be separated from the accident. In a carriage, in the event of an accident then apply provisions of Law No. 22 of 2009 on Traffic and Transportation. If there is a loss that hit the third party then setting responsibilities Public Service Agency TransJakarta Busway to third parties refer to the provisions of Article 194 paragraph (1) which determines that the public transport companies are not responsible for any losses suffered by third parties, unless the third party may prove that the loss is caused by the fault of public transport company. Under these provisions, if the third party wants to sue for damages, ketigalah party must prove the fault of the carrier, the claim is based on the basis of tort or on the basis of error set forth in Article 1365 of the Civil Code which stipulates that any action unlawfully harming others, require the person who carries the loss offset.
\end{abstract}

Keywords: transport, the responsibility of the carrier, a third party, transport law

Abstrak

Tujuan pembangunan busway adalah untuk memberikan jasa angkutan yang lebih cepat, aman, nyaman, serta terjangkau bagi warga Jakarta. Harga tiket busway disubsidi oleh pemerintah daerah. Busway diberikan jalur khusus, meski demikian tak lepas dari kecelakaan. Dalam suatu pengangkutan, apabila terjadi kecelakaan maka berlakulah ketentuan UU No. 22 Tahun 2009 tentang Lalu Lintas dan Angkutan Jalan. Jika terjadi kerugian yang menimpa pihak ketiga maka pengaturan tanggung jawab Badan Layanan Umum Transjakarta Busway terhadap pihak ketiga mengacu kepada ketentuan Pasal 194 ayat (1) UULAJ yang menentukan bahwa perusahaan angkutan umum tidak bertanggung jawab atas kerugian yang diderita pihak ketiga, kecuali jika pihak ketiga dapat membuktikan bahwa kerugian tersebut disebabkan oleh kesalahan perusahaan angkutan umum. Berdasarkan ketentuan tersebut, apabila pihak ketiga ingin menuntut ganti kerugian, pihak ketigalah harus membuktikan adanya kesalahan dari perusahaan angkutan, tuntutan tersebut didasarkan atas dasar perbuatan melawan hukum atau atas dasar kesalahan yang diatur dalam Pasal 1365 Kitab Undang-Undang Hukum Perdata yang menentukan bahwa setiap perbuatan melawan hukum yang merugikan orang lain, mewajibkan orang yang membawa kerugian tersebut mengganti kerugian.

Kata kunci: pengangkutan, tanggung jawab pengangkut, pihak ketiga, hukum pengangkutan

\section{Pendahuluan}

Menurut data dari Pemprov DKI Jakarta yang disampaikan pada Rakornis Perhubungan Darat di Surabaya, rata-rata pertumbuhan kendaraan pribadi meningkat 9,1 per tahun. Pemprov DKI Jakarta memproyeksikan, dengan partumbuhan jumlah kendaraan yang begitu besar, apabila penggunaan kendaraan pribadi tidak di- kendalikan, maka Jakarta akan macet total pada tahun -tahun ke depan. Tahun 2010 diperkirakan akan naik hingga 55,1 \% apabila penggunaan busway tidak menjadi prioritas utama dalam pemakaian angkutan. Hal ini berakibat rendahnya tingkat pemakaian dari angkutan publik hingga $44,1 \%$ sehingga tinggi kemacetan yang terjadi di Kota Jakarta semakin sering terjadi seperti yang 
telah diprediksikan, bahwa tahun 2014 terjadi kemacetan dimana-mana, dan ini benar adanya, seperti yang dihadapi pada saat ini.

Data dari Dinas Perhubungan Provinsi Daerah Khusus Ibukota Jakarta menunjukkan kondisi Transportasi Jakarta pada saat ini adalah sebagai berikut. ${ }^{1}$ Pertama, perkembangan jumlah kendaraan bermotor terus meningkat, saat ini berjumlah sekitar 5,4 juta unit, rata-rata meningkat 9,5 persen pertahun ( 5 tahun terakhir); kedua, setiap harinya tidak kurang dari 669 kendaraan mengajukan STNK baru yang memerlukan jalan sepanjang $828 \mathrm{~m}$; ketiga, terdapat 600.000 kendaraan $(1,2$ juta orang) dari BODETABEK masuk Jakarta setiap harinya; keempat, jumlah kendaraan bermotor yang bergerak setiap harinya mencapai 4,95 juta (kendaraan roda dua 53 persen, mobil pribadi 30 persen, bis 7 persen dan truk 10 persen); kelima, rasio jumlah kendaraan pribadi adalah 98 persen, angkutan umum 2 persen. Rasio penggunaan kendaraan pribadi dibandingkan kendaraan umum adalah 44 persen dibanding 56 persen dari total 17,2 juta perjalanan/hari; keenam, kemampuan menambah ruas jalan semakin sulit dibandingkan penambahan kendaraan. Panjang jalanan hanya bertambah kurang dari satu persen, sedangkan penambahan kendaraan rata-rata 11 persen pertahun; ketujuh, 85 persen ruang jalan yang ada digunakan oleh kendaraan pribadi yang sebenarnya hanya melayani 9,7 persen perjalanan (mobil); dan kedelapan, kondisi angkutan umum sangat memprihatinkan dan dari tahun ke tahun jumlahnya semakin berkurang.

Setiap orang memerlukan alat transportasi yang cepat, aman, dan nyaman serta menghindari kemacetan yang seringkali terjadi di Jakarta, untuk itulah pada tanggal 15 Januari 2004, diluncurkan sistem angkutan massal dengan nama bus Transjakarta atau lebih popular disebut Busway sebagai bagian dari sebuah sistem transportasi baru kota. Setelah sukses dengan koridor I, pengangkutan massal dikembangkan ke koridor-koridor berikutnya. Transjakarta atau umum disebut Busway adalah sebuah sistem transpor-

Informasi Transportasi Jakarta, Data Dinas Perhubungan Daerah Khusus Ibukota Jakarta, 28 April 2010. tasi bus cepat atau Bus Rapid Transit di Jakarta. Sistem ini dimodelkan berdasarkan sistem TransMilenio yang sukses di Bogota, Kolombia. Perencanaan busway telah di mulai sejak tahun 1997 oleh konsultan dari Inggris. Pada waktu itu direncanakan bus berjalan berlawanan dengan arus lalu-lintas supaya jalur tidak diserobot kendaraan lain, namun dibatalkan dengan pertimbangan keselamatan lalu-lintas. Meskipun busway di Jakarta meniru negara lain (Kolombia, Jepang, Australia), namun Jakarta memiliki jalur yang terpanjang dan terbanyak, sehingga kalau dulu orang melihat ke Bogota, sekarang Jakarta sebagai contoh yang perlu dipelajari masalah dan cara penanggulangannya. ${ }^{2}$

Pemecahan masalah kemacetan di Kota Jakarta tidak dapat terselesaikan dengan pengadaan Angkutan Umum Penumpang ini saja, namun juga dengan pengembangan infrastruktur yang mendukung. Perkembangan jumlah armada BRT (Bus Rapid Transit) di Jakarta semakin besar dan sampai tahun 2009 mencapai 419 bus untuk melayani 8.513.385 penduduk di Jakarta. Jangkauan sistem BRT juga semakin luas dengan bertambahnya jumlah koridor yang beroperasi. Kinerja BRT juga dapat diketahui semakin baik dengan meningkatnya volume penumpang yang terangkut hingga mencapai sekitar 83 juta. Secara rata-rata, sebuah bus dalam setahun mengangkut 175191 penumpang pada tahun 2004 menjadi 208490 penumpang 2009. Akan tetapi pertumbuhan kendaraan pribadi di Ibu Kota kian tak terkendali.

Namun, buruknya sistem transportasi massal membuat warga enggan beralih ke angkutan umum. Bahkan keberadaan Bus Transjakarta pun belum membuat masyarakat merasa nyaman. Moda transportasi yang diluncurkan 2004 itu baru berhasil mengalihkan sekitar 22,5 persen pengguna kendaraan pribadi. Data Institute for Transportation and Development Policy menunjukkan, pengguna mobil yang beralih ke bus berjalur khusus itu atau busway hanya 7,1 persen, dan pengguna sepeda motor 15,4 persen, sedangkan sisanya merupakan peralihan penum-

Bus Transjakarta 2009, (On-line), tersedia di: http://id. wikipedia.org/wiki/Transjakarta (4 Maret 2010). 
pang angkutan umum reguler seperti metromini dan mikrolet.

Ada beberapa tujuan Pemerintah Daerah Daerah Khusus Ibukota Jakarta dalam pembangunan busway ini. ${ }^{3}$ Pertama, meningkatkan jumlah perjalanan penumpang dengan menggunakan transportasi bus yang aman, nyaman, dan handal; kedua, menciptakan sistem transportasi dengan jalur yang terpisah dari lalu lintas umum untuk kemudahan aksessibilitas; ketiga, menciptakan sistem transportasi dengan pelayanan terjadwal; keempat, meningkatkan pelayanan angkutan umum yang terintegrasi; dan kelima, menerapkan sistem collecting pendapatan tiket yang efektif.

Badan Layanan Umum (selanjutnya disebut BLU) Transjakarta Busway adalah lembaga yang dibentuk oleh Pemerintah Provinsi Daerah Khusus Ibukota Jakarta untuk mengelola layanan angkutan umum massal dengan menggunakan moda bus. Pembangunan Bus Rapid Transit (BRT) merupakan salah satu strategi dari Pola Transportasi Makro (PTM) untuk meningkatkan pelayanan dan penyediaan jasa transportasi yang aman, terpadu, tertib, lancar, nyaman, ekonomis, efisien, efektif, dan terjangkau oleh masyarakat. Bus Rapid Transit (BRT) yang difasilitasi dengan jalur, armada bus dan infrastruktur yang dibangun khusu, sistem tiket elektronik yang saat ini dioperasikan di koridor 1-3 serta keramahan petugas adalah layanan yang diberikan kepada masyarakat untuk dapat menggunakan angkutan umum yang lebih baik. Kini masyarakat mempunyai alternative angkutan umum yang memberikan kemudahan memberikan menjangkau seluruh wilayah Jakarta dengan pelayanan yang berbeda dengan dibandingkan dengan angkutan umum lainnya. ${ }^{4}$

Busway sendiri idenya adalah memberikan alternatif transportasi massal bagi warga Jakarta. Selain itu tujuan pembangunan busway adalah untuk memberikan jasa angkutan yang lebih

Tujuan Pembangunan Busway Transjakarta, (On-line), tersedia di: http://www.dishubdki.info/busway.php (25 Maret 2010).

4 Company Profile Badan Layanan Umum Transjakarta Busway

5 Lihat dan bandingkan dengan I G A Wahyu Nugraha, Nyoman A. Martana, "Perlindungan Hukum terhadap Penum- cepat, aman, nyaman, serta terjangkau bagi warga Jakarta. Untuk mencapai hal tersebut busway diberikan jalur khusus di jalan-jalan yang menjadi bagian dari rutenya dan jalur tersebut tidak boleh dilewati kendaraan lainnya (termasuk bus umum selain Transjakarta). Agar terjangkau oleh masyarakat, maka harga tiket disubsidi oleh pemerintah daerah. Namun seberapa primanya suatu pelayanan yang diberikan oleh perusahaan angkutan, terkadang tidak terlepas pula dari suatu kecelakaan. Oleh karena itu, apabila didalam suatu pengangkutan terjadi suatu kecelakaan maka berlakulah ketentuan yang terdapat di dalam Undang-undang Nomor 22 Tahun 2009 tentang Lalu Lintas dan Angkutan Jalan. ${ }^{5}$

Berdasarkan penjelasan di atas, maka dikemukakan suatu permasalahan yang menyangkut peraturan yang mengatur tentang Bagaimana pengaturan tanggung jawab BLU Transjakarta terhadap pihak ketiga dalam hal terjadi kecelakaan menurut Undang-undang Nomor 22 Tahun 2009 tentang Lalu Lintas dan Angkutan Jalan?. Oleh karena itu disampaikan penulisan tentang "Tanggung Jawab Badan Layanan Umum Transjakarta Terhadap Pihak Ketiga Dalam Hal Terjadi Kecelakaan Menurut Undang-Undang Nomor 22 Tahun 2009 Tentang Lalu Lintas dan Angkutan Jalan".

Tanggung jawab Badan Layanan Umum Transjakarta Terhadap Pihak Ketiga dalam hal Terjadi Kecelakaan Menurut Undang-Undang Nomor 22 Tahun 2009 tentang Lalu Lintas dan Angkutan Jalan

Subjek hukum dalam pengertian hukum yang berlaku umum adalah pendukung hak dan kewajiban. Kemudian dalam hukum pengangkutan, bahwa pihak-pihak yang terlibat disebut dengan subjek hukum. Subjek hukum pengangkutan adalah pendukung hak dan kewajiban dalam hubungan hukum pengangkutan, yaitu para pi-

pang Tanpa Tiket (Illegal) dalam Pengangkutan Darat di Indonesia”, Jurnal Kertha Semaya, Vol. 02, No. 01, Februari 2014, Denpasar: Program Studi Ilmu Hukum Fakultas Hukum Universitas Udayana; E. Saefullah Wiradipradja, "Tanggung Jawab Perusahaan Penerbangan Terhadap Penumpang Menurut Hukum Udara Indonesia”, Jurnal Hukum Bisnis, Vol 25. 2006, Jakarta. 
hak yang berkepentingan di dalam pengangkutan. ${ }^{6}$

Subjek hukum dalam hukum pengangkutan dibagi menjadi 2 (dua) bagian, yaitu: ${ }^{7}$ pihak-pihak yang berkepentingan secara langsung dan terikat dalam perjanjian pengangkutan; dan pihak-pihak yang secara tidak langsung terikat dalam perjanjian pengangkutan, padahal mereka bukan pihak yang berkedudukan dalam perjanjian namun mereka bertindak atas nama atau kepentingan pihak lain. Adapun Pihak-pihak yang berkepentingan secara langsung terikat dalam perjanjian pengangkutan adalah sebagai berikut. ${ }^{8}$ Pertama, pengangkut (carrier). Istilah "pengangkut" mempunyai 2 (dua) arti yaitu sebagai pihak penyelenggara pengangkutan dan sebagai alat yang digunakan untuk menyelenggarakan pengangkutan. Pengangkut sebagai pihak penyelenggara pengangkutan bisa kita lihat dan kita ambil definisinya dari pengertian perjanjian pengangkutan yaitu adalah pihak yang mengikatkan diri untuk menyelenggarakan pengangkutan barang dan atau penumpang dari suatu tempat ke tempat tujuan lain dengan selamat.

Kedua, pengirim (consigner, shipper). Pengirim adalah pihak yang mengikatkan diri untuk memabayar biaya angkutan. Biasanya pengirim ini adalah pemilik barang. Pengirim merupakan orang dan atau badan hukum yang menggunakan jasa angkutan untuk mengirimkan barangnya dari suatu tempat semula ke tempat tujuan untuk maksud tertentu baik menggunakan jalur darat, laut maupun udara. Pengirim yang menggunakan jasa angkutan ini biasanya dilengkapi dengan dokumen angkut, karena menggunakan jasa ini untuk mengirimkan barang sebagai tanda bukti bahwa ia memiliki barang tersebut dan berhak atasnya adalah dokumen angkutan yang biasa-

6 Abdulkadir Muhammad, 1991. Hukum Pengangkutan Darat, Laut dan Udara, Bandung: PT. Citra Aditya Bakti, $\mathrm{hlm} .33$.

7 Elfrida Gultom, 2008, Hukum Pengangkutan Darat, Jakarta: PT. Literata Lintas Media, hlm. 19.

$8 \mathrm{lbid}, \mathrm{hlm}$. 20. Bandingkan dengan pihak yang berkepentingan dalam pengangkutan laut pada Taufiq Yulianto, "Mekanisme Pengangkutan Barang Melalui Laut Ditinjau dari Sudut Hukum Pengangkutan, Orbith, Vol. 9 No. 3 November 2013, hlm. 223-227.

$9 \quad$ Ibid

10 Ibid, hal. 22. nya berisi nama pemilik, tempat tujuan dan isi dari kiriman tersebut.

Ketiga, penumpang atau pengguna jasa (passanger). Penumpang mempunyai 2 (dua) kedudukan, yaitu sebagai subjek hukum pengangkutan karena merupakan pihak yang secara langsung terikat pada perjanjian sedangkan sebagai objek karena ia adalah muatan yang diangkut. Jadi dalam hal ini, penumpang sebagai pengguna jasa yang menikmati langsung jasa yang diberikan oleh pengangkut dan wajib membayar kontra prestasi kepada pengangkut yaitu dengan membayar uang angkut. Selain pihak-pi-hak yang secara langsung terikat dengan perjan-jian pengangkutan maka ada juga pihak-pihak yang tidak secara langsung terikat dengan per-janjian pengangkutan, adapun pihak-pihak ter-sebut adalah: ${ }^{9}$

Keempat, pihak ketiga. Pihak ketiga adalah pihak yang tidak turut langsung mengadakan perjanjian pengangkutan dengan pengangkut atau dengan kata lain di luar perjanjian namun apabila terjadi sesuatu hal dari pengangkutan dan mengenai si pihak ini maka pihak ini dapat menuntut ganti rugi kepada pengangkut. Pihak Ketiga yang dimaksud disini contohnya: pejalan kaki; dan pengendara kendaraan bermotor, dan lain sebagainya. ${ }^{10}$ Kelima, pihak asuransi. Adanya perusahaan asuransi di sini terkait dengan "kewajiban" dari pengangkut untuk mengasuransikan tanggung jawabnya dalam rangka penyelenggaraan kegiatan pengangkutan. ${ }^{11}$

Terdapat 5 (lima) prinsip tanggung jawab dalam hukum pengangkutan. Prinsip tersebut digunakan untuk mengetahui sistem ganti rugi apabila terjadi suatu risiko dalam suatu pengangkutan. Dimana tanggung jawab dalam konteks hukum pengangkutan ini biasa disebut de-

11 Lihat dan bandingkan mengenai perlindungan hukum tertanggung ini dengan artikel dari Darmadi Charisma Putra, I Ketut Markeling, I Made Dedy Priyanto, "Perlindungan Hukum terhadap Pihak Tertanggung dalam Asuransi Demam Berdarah pada Pt. Asuransi Central Asia”, Jurnal Kertha Semaya, Vol. 02, No. 04, Juni 2014, Denpasar: Program Studi Ilmu Hukum Fakultas Hukum Universitas Udayana; Ridwan Khairandy, "Tanggung Jawab Pengangkut dan Asuransi Tanggung Jawab Sebagai Instrumen Perlindungan Konsumen Angkutan Udara", Jurnal Hukum Bisnis, Vol 25, 2006, Jakarta; dan Sunarmi, "Pemegang Polis Asuransi dan Kedudukan Hukumnya", Jurnal Ilmu Hukum, Vol. 3 No. 1 2012, Pekanbaru: FH Univ. Riau. 
ngan liability atau tanggung jawab. ${ }^{12}$ Tanggung jawab atau liability adalah suatu keharusan di mana seseorang harus melaksanakan dengan layak suatu pengangkutan dan apabila orang tersebut tidak melaksanakan dengan layak apa yang telah menjadi kewajibannya, maka orang tidak tersebut tidak dapat melaksanakan pengangkutan yang tidak layak tersebut harus memberikan ganti rugi. ${ }^{13}$

Sebagaimana telah diuraikan sebelumnya, bahwa dalam perjanjian pengangkutan terkait kepentingan dua pihak, yaitu pengangkut dan pengguna jasa. Adanya kesepakatan dalam melaksanakan perjanjian pengangkutan melahirkan hak dan kewajiban yang harus dipenuhi oleh para pihak. Secara umum, hak dari pengangkut adalah menentukan dan menerima uang pembayaran dari pengguna jasa, untuk hak tersebut itu pengangkut bertanggung jawab dan berkewajiban untuk menyelenggarakan pengangkutan dengan selamat dari suatu tempat ke tempat tujuan tertentu sesuai dengan kesepakatan di dalam perjanjian pengangkutan yang dibuat. Di lain pihak, pengguna jasa angkutan wajib membayar biaya angkutan sesuai kesepakatan di dalam perjanjian pengangkutan yang dibuatnya, dan pengguna jasa dapat menuntut haknya berupa jaminan keselamatan hingga tiba di tempat tujuan (untuk pengangkutan orang) atau hingga barang yang dikirimkan diterima oleh penerima barang yang telah ditunjuk oleh pengirim. ${ }^{14}$

Tanggung jawab adalah kondisi yang mewajibkan seseorang harus menanggung sesuatu, jika terjadi hal yang tidak dikehendaki, orang tersebut boleh disalahkan, diperkarakan, dituntut dan sebagainya. Tanggung jawab dalam pengangkutan terbagi dalam 2 (dua) macam. ${ }^{15}$ Pertama, liability. Liability adalah tanggung jawab yang didasarkan pada keharusan seseorang yang menimbulkan kesalahan untuk membayar ganti rugi atas kesalahan yang ia timbulkan. Kedua, responsibility. Responsibility adalah jenis tanggung jawab yang didasarkan pada hati nurani se-

Elfrida Gultom, op.cit, hlm. 23.

13 Ibid.

14 Ibid. Lihat dan bandingkan dengan tanggung jawab pengangkut udara pada Muazzin, “Tanggung Jawab Pangang- seorang yang menerbitkan kesalahan. Ini merupakan jenis tanggung jawab moril.

Minimal ada 2 (dua) pihak terkait dalam perjanjian pengangkutan. Di dalam perjanjian pengangkutan pihak-pihak yang terkait langsung adalah pengangkut dan pengguna jasa. Imbas dari perjanjian tersebut adalah masing-masing subjek pengangkutan akan mengemban hak dan kewajiban yang harus dipenuhi. Pengangkut mempunyai hak untuk menerima pembayaran sebagai kontra prestasi dari jasa yang ia berikan kepada pengguna jasa dan sebagai gantinya adalah pengangkut mempunyai kewajiban untuk mengangkut pengguna jasa dari tempat semula dan mengantarkan pengguna jasa atau penumpang ke tempat tujuan dengan "selamat". Di lain sisi pengguna jasa juga mempunyai hak untuk mendapatkan perlakuan yang baik dari pengangkut dan mendapatkan itikad baik dari pengangkut agar mengantarkannya ke tempat tujuan dengan selamat dan sebagai gantinya pengguna jasa berkewajiban untuk membayar ongkos angkut kepada pengangkut sesuai dengan perjanjian pengangkutan yang disepakati.

Apabila dilihat dari hal tersebut diatas maka masing-masing pihak mempunyai "tanggung Jawab" untuk memenuhi hak dan kewajibannya. Dalam ilmu hukum, khususnya hukum pengangkutan, dikenal adanya prinsip-prinsip tanggung jawab di bidang angkutan. Prinsip-prinsip tanggung jawab ini berkaitan dengan tanggung jawab pengangkut untuk membayar ganti kerugian kepada pegguna jasa. Beberapa prinsip tanggung jawab tersebut adalah sebagai berikut.

Pertama, prinsip tanggung jawab berdasarkan atas kesalahan (based on fault). Prinsip ini diatur dalam Pasal 1365 KUHPerdata yang menentukan bahwa tiap perbuatan melanggar hukum yang membawa kerugian kepada seorang lain, mewajibkan orang yang karena salahnya menerbitkan kerugian itu, mengganti kerugian tersebut. Pasal ini dikenal dengan pasal tentang 
perbuatan melawan hukum (onrechtmatigedaad). ${ }^{16}$

Titik tolak pengertian perbuatan melawan hukum adalah Pasal 1365 KUHPerdata tersebut, sebagaimana diberi penafsiran dalam putusan Hoge Raad (Mahkamah Agung) Belanda tanggal 31 Januari 1919, yang diikuti juga oleh pengadilan di Indonesia. Menurut Yurisprudensi, suatu perbuatan melawan hukum adalah suatu perbuatan yang: melanggar hak orang lain; bertentangan dengan kewajiban hukum yang berbuat; bertentangan dengan kepatutan yang terdapat dalam masyarakat tentang diri/barang orang lain; atau bertentangan dengan kesusilaan yang baik.

Tafsiran ini sangat luas, sehingga dalam bidang angkutan, pelanggaran peraturan lalu lintas oleh pengangkut atau oleh pegawainya juga termasuk dalam perbuatan melawan hukum, namun selama perbuatan itu tidak langsung mengenai kewajibannya terhadap pengguna jasa angkutan, merupakan tanggung jawab sendiri dari pengangkut, tetapi perbuatan tersebut harus diperhitungkan apabila karena perbuatan tersebut pihak pengguna jasa angkutan mengalami kerugian dan akan mempunyai akibat terhadap masalah tanggung jawab pengangkut terhadap pengguna jasa angkutan.

Akibat terpenting yang diatur dalam Pasal 1365 KUHPerdata adalah tanggung jawab pihak yang melakukan perbuatan melawan hukum, berupa kewajibannya membayar ganti kerugian. Dapat dikemukakan bahwa tanggung jawab menurut pasal tersebut adalah tanggung jawab berdasarkan atas kesalahan yang harus dibuktikan oleh pihak yang menuntut ganti kerugian. Selain itu menurut Pasal 1365 KUHPerdata, tanggung jawab seseorang bisa juga diakibatkan karena kelalaian atau kurang hati-hatinya.

Pada prinsip ini jelas bahwa beban pembuktian ada pada pihak yang dirugikan, artinya pihak yang dirugikan yang harus membuktikan bahwa kerugiannya diakibatkan oleh perbuatan melawan hukum, sebagaimana ditentukan dalam Pasal 1865 KUHPerdata bahwa setiap orang

16 Bandingkan dengan tulisan Ida Bagus Bayu Mahardika dan I Ketut Sandhi Sudarsana, "Perbuatan Melanggar Hukum oleh Maskapai Penerbangan Terkait Pembatalan dan Ke- yang mendalilkan bahwa ia mempunyai sesuatu hak atau guna meneguhkan haknya sendiri atau membantah sesuatu hak orang lain, menunjuk pada suatu peristiwa, diwajibkan membuktikan adanya hak atau peristiwa tersebut. Dan prinsip based on fault ini tidak didasarkan pada perjanjian, tetapi dengan perbuatan melawan hukum tersebut juga menimbulkan perikatan, sebagaimana di tentukan dalam Pasal 1353 KUHPerdata. Dalam praktek, prinsip tanggung jawab dalam KUHPerdata ini tidak berperan dalam bidang angkutan, karena telah diatur dalam lex specialis.

Kedua, prinsip tanggung jawab berdasarkan praduga bahwa pengangkut dianggap selalu bertanggung jawab (presumption of liability). ${ }^{17}$ Prinsip ini merupakan prinsip "praduga bahwa pengangkut selalu bertanggung jawab”, tanpa ada keharusan bagi pihak yang dirugikan untuk membuktikan bahwa ada perbuatan melawan hukum dari pihak pengangkut atau tidak.

Prinsip ini didasarkan pada perjanjian pengangkutan, tetapi pengangkut dapat membebaskan diri dari tanggung jawabnya, apabila pengangkut dapat membuktikan bahwa: (a) kerugian yang disebabkan oleh malapetaka yang selayaknya tidak dapat dicegah atau dihindarinya atau berada di luar kekuasaannya; (b) ia telah mengambil semua tindakan yang diperlukan untuk menghindari timbulnya kerugian; (c) kerugian yang timbul bukan karena kesalahannya; dan (d) kerugian ditimbulkan oleh kelalaian atau kesalahan dari penumpang sendiri atau karena cacat, sifat atau mutu barang yang diangkut.

Mula-mula harus dikemukakan bahwa praduga bahwa pengangkut selalu bertanggung jawab tidak sama dengan praduga bahwa pengangkut bersalah, karena justru unsur kesalahan inilah yang tidak menentukan dalam hal ada atau tidaknya tanggung jawab pengangkut. Menurut prinsip "praduga bahwa pengangkut selalu bertanggung jawab", pengangkut bertanggung jawab dengan tidak mempersoalkan, apakah pengangkut bersalah atau tidak, atau dengan kata lain, unsur kesalahan tidak menentukan ada

terlambatan Pengangkutan", Jurnal Kertha Semaya, Vol. 02 No. 1 Februari 2014, Denpasar: FH Univ. Udayana.

17 Elfrida Gultom, op.cit, hlm. 28-31. 
atau tidaknya tanggung jawab pengangkut. Dengan demikian, maka dasar dari prinsip ini sudah pasti bukanlah suatu perbuatan melawan hukum yang dilakukan pengangkut, sehingga harus dicari dasar lain.

Jika tanggung jawab pengangkut bukan atas perbuatan melawan hukum (delictual liability) maka, kemungkinan yang lain hanyalah bahwa tanggung jawab pengangkut berdasarkan suatu kontrak atau perjanjian (contractual liability), yaitu tanggung jawab pengangkut yang mengadakan perjanjian dengan pengguna jasa, bila perjanjian tersebut tidak dipenuhi, kurang dipenuhi atau terlambat dipenuhi. Adapun alasan-alasan untuk mempergunakan prinsip praduga bahwa pengangkut selalu dianggap bertanggung jawab dan beban pembuktian diletakkan pada pengangkut didasarkan pada teori-teori sebagai berikut: (a) pengangkut dalam menjalankan usahanya dapat menimbulkan bahaya terhadap pihak lain; (b) pengangkut harus memikul risiko untuk usaha-usaha yang dijalankannya; (c) pengangkut mendapat keuntungan dari usahanya; dan (d) dipergunakan alat angkut, sehingga segala kerugian yang disebabkan oleh alat angkut harus ditanggung oleh pengangkut.

Berdasar prinsip ini, adanya tanggung jawab pengangkut, tidak tergantung pada adanya kesalahan dari pengangkut, karena justru apabila ada kesalahan pada pengangkut, maka prinsip "praduga bahwa pengangkut selalu bertanggung jawab" tidak berlaku lagi dan unsur kesalahan ini harus dibuktikan oleh pihak yang dirugikan, dengan kata lain tanggung jawab pengangkut tidak merupakan praduga (presumed) lagi. Hal ini tentunya dapat merubah tanggung jawab pengangkut berdasarkan kontrak atau perjanjian menjadi tanggung jawab berdasarkan atas kesalahan atau perbuatan melawan hukum.

Antara prinsip based on fault dengan prinsip "praduga bahwa pengangkut selalu bertanggung jawab" tersebut mempunyai perbedaan yang sangat mendasar, yaitu prinsip based on fault tidak didasarkan pada adanya suatu kontrak atau perjanjian dan beban pembuktiannya ada pada pihak yang dirugikan dalam hal ini ada- lah pihak pengguna jasa angkutan, sedangkan prinsip "praduga bahwa pengangkut selalu bertanggung jawab" selalu didasarkan pada adanya suatu kontrak atau perjanjian dan beban pembuktiannya terletak pada pengangkut.

Ketiga, prinsip tanggung jawab berdasarkan praduga bahwa pengangkut selalu tidak dianggap bertanggung jawab (presumption of non liability). ${ }^{18}$ Prinsip ini merupakan prinsip "praduga bahwa pengangkut selalu tidak bertanggung jawab", untuk barang bawaan yang berada di dalam pengawasan penumpang sendiri, contohnya adalah bagasi tangan, dan beban pembuktian adanya tanggung jawab pengangkut terletak pada penumpang dan tanggung jawab ini baru ada, apabila ada kesalahan dari pengangkut. Prinsip didasarkan pada perjanjian pengangkutan. Dengan adanya prinsip ini, maka ada kemungkinan tidak ada satu pihak pun yang dapat dipertanggung jawabkan mengenai kerugian terhadap barang bawaan yang berada dalam pengawasan penumpang sendiri, yaitu apabila penumpang membuktikan bahwa ia telah mengambil tindakan seperlunya untuk menjaga barang tersebut, sedangkan pengangkut juga telah membuktikan bahwa ia tidak mungkin dapat mencegah timbulnya kerugian. Dengan demikian, maka penumpang sendirilah yang harus memikul kerugiannya.

Kekhususan dari prinsip ini adalah ditujukan khusus pada barang bawaan yang berada dalam pengawasan penumpang sendiri, yang didasarkan pada perjanjian, di mana beban pembuktian ada pada penumpang karena barang sepenuhnya berada dalam pengawasan penumpang sendiri dan berarti menjadi tanggung jawab penumpang sendiri. Prinsip presumption of non liability mempunyai persamaan dengan prinsip based on fault, yaitu pihak yang harus membuktikan adalah pihak penumpang atau pihak ketiga, sebagai pihak yang dirugikan, tetapi juga mempunyai perbedaan, yaitu pada prinsip based on fault tidak didasarkan pada perjanjian, sedangkan pada presumption of non liability, didasarkan pada perjanjian.

$18 \quad$ Ibid, hlm. 31-33. 
Keempat, prinsip tanggung jawab multlak (absolute atau strict liability). ${ }^{19}$ Prinsip ini mengandung pengertian, bahwa secara yuridis salah atau tidak salah, pengangkut harus bertanggung jawab, dengan tidak ada beban pembuktian. Hal ini berarti, pihak pengangkut selalu bertanggung jawab tanpa melihat ada atau tidak adanya kesalahan atau tidak melihat siapa yang bersalah, atau suatu prinsip tanggung jawab yang memandang kesalahan sebagai suatu yang tidak relevan untuk dipermasalahkan apakah pada kenyataannya ada atau tidak ada.

Kelima, prinsip pembatasan tanggung jawab (limitation of liability). ${ }^{20}$ Prinsip ini berhubungan dengan semua prinsip tanggung jawab yang telah dikemukakan, yaitu baik based on fault, presumption of liability maupun absolute liability. Pembatasan tanggung jawab pengangkut, pada dasarnya merupakan pembatasan dalam jumlah ganti rugi yang harus dijabarkan dalam ketentuan perundangan dibidang angkutan.

Ada beberapa alasan dipergunakannya prinsip ini. Pertama, dalam kegiatan pengangkutan, risiko terbesar ada pada pengangkut, maka sudah sepantasnya risiko itu dibatasi, walau pun mungkin dipandang dari sudut moral, pembatasan tanggung jawab dalam hal seorang penumpang menderita luka-luka atau meninggal adalah tidak pantas, akan tetapi prinsip pembatasan tanggung jawab ini sebagai suatu prinsip harus tetap ada, dan ketidakpentasan penggunaannya dalam praktek dapat dihindarkan apabila terdapat alasan-alasan yang kuat menurut kebijakan hakim-hakim yang dapat menyelesaiakn perkaranya; kedua, agar pengangkut tidak boleh mengadakan syarat-syarat perjanjian pengangkutan yang meniadakan tanggung jawabnya; dan ketiga, adanya limit-limit tertentu sebagai dasar untuk menyelesaikan tuntutan-tuntutan ganti rugi dengan secepat-cepatnya dan semudah-mudahnya tanpa harus meminta perantaraan hakim lagi. Setidak-tidaknya pencantuman limit ganti rugi dalam peraturan perundang-undangan di bidang angkutan akan memberikan pedoman atau patokan yang jelas, baik bagi pengangkut mau- pun pihak yang menuntut ganti rugi, mengenai ganti rugi yang harus dibayarkan.

Prinsip pembatasan tanggung jawab ini ada yang bersifat breakable limit dan unbreakable limit. Breakable limit, artinya dapat dilampaui dan tidak bersifat mutlak, di mana ganti rugi yang diberikan oleh pengangkut masih dapat dimungkinkan untuk dibayarkan melebihi jumlah yang dinyatakan, yaitu dalam hal kerugian disebabkan oleh adanya perbuatan sengaja (willful misconduct) atau kelalaian berat (gross negligence) dari pengangkut. Unbreakable limit, artinya tidak dapat dilampaui dengan alasan apa pun. Hal ini berarti tanggung jawab pengangkut dan ganti rugi yang harus dibayarkan tidak boleh melebihi jumlah yang dinyatakan.

Periode tanggung jawab ini sebenarnya sudah dapat kita lihat dan tersirat dari perjanjian pengangkutan. Di dalam perjanjian ini kita dapat lihat periode tanggung jawab pengangkut dimulai saat penumpang itu diangkut dari tempat semula oleh pengangkut sampai penumpang di turunkan di tempat tujuan yang telah di sepakati pada saat perjanjian sebelumnya dengan selamat. ${ }^{21}$ Periode tanggung jawab pengangkut ini yang menentukan kapan saat tanggung jawab pengangkut dimulai dan kapan saat berakhirnya tanggung jawab itu. ${ }^{22}$

Kewajiban dari pengangkut adalah menyelenggarakan pengangkutan barang dan/atau orang dari suatu tempat ke tempat tujuan dengan selamat, namun apabila pengangkut tidak dapat mengantarkan penumpang ketempat tujuan dengan selamat, maka akan menjadi tanggung jawab pengangkut untuk membayar ganti kerugian kepada penumpang yang berada dalam alat pengangkutan yang disediakan oleh pengangkut. Tanggung jawab pengangkut terhadap penumpang dalam hal ini sebagai penyelenggara sarana angkutan jalan diatur dalam Pasal 192 ayat (1) UULAJ menentukan bahwa perusahaan angkutan umum bertanggung jawab atas kerugian yang diderita oleh penumpang yang meninggal dunia atau luka akibat penyelenggaraan angkutan, kecuali disebabkan oleh suatu kejadian 
yang tidak dapat dicegah atau dihindari atau karena kesalahan penumpang. Berdasarkan ketentuan ayat diatas ada 4 (empat) hal yang sekalian diatur. Pertama, tanggung jawab perusahaan angkutan umum untuk mengganti kerugian; kedua, ganti kerugian tersebut diberikan kepada penumpang yang meninggal dunia atau lukaluka; ketiga, kerugian terjadi akibat penyelenggaraan angkutan; dan keempat, dikaitkan dengan teori prinsip-prinsip tanggung jawab di bidang angkutan maka sistem tanggung jawab yang dianut adalah presumption of liability atau prinsip tanggung jawab berdasarkan praduga bahwa pengangkut dianggap selalu bertanggung jawab. Hal ini dapat diketahui dari kalimat "kecuali disebabkan oleh suatu kejadian yang tidak dapat dicegah atau dihindari atau karena kesalahan penumpang". Berdasarkan tanggung jawab ini perusahaan angkutan umum haruslah membuktikan salah satu dari dua hal yaitu: disebabkan oleh salah satu kejadian yang tidak dapat dicegah atau dihindari atau overmacht atau force majeur; dan karena kesalahan penumpang sendiri.

Untuk tanggung jawab terhadap pihak ketiga dalam UULAJ tidak diatur, hal ini dapat dilihat dari Pasal 194 ayat (1) yang menentukan bahwa perusahaan angkutan umum tidak bertanggung jawab atas kerugian yang diderita oleh pihak ketiga, kecuali jika pihak ketiga dapat membuktikan bahwa kerugian tersebut disebabkan oleh kesalahan perusahaan angkutan umum. Sistem tanggung jawab yang diatur dalam ayat ini adalah sistem berdasarkan atas kesalahan atau based on fault, karena antara pihak ketiga dengan perusahaan angkutan tidak terdapat perjanjian. Besarnya ganti rugi tidak diatur hanyalah jangka waktu untuk mengajukan keberatan dan permintaan ganti kerugian dari pihak ketiga, disampaikan selambat-lambatnya 30 (tiga puluh) hari terhitung mulai tanggal terjadinya kerugian, sebagaimana ditentukan dalam Pasal 194 ayat (2). ${ }^{23}$

Limit atau batas jumlah ganti rugi yang harus dibayarkan oleh perusahaan angkutan kepada penumpang yang meninggal dunia atau lu- ka-luka, yang ditentukan dalam Pasal 192 ayat (2) UULAJ yang menyebutkan bahwa kerugian sebagaimana dimaksud pada ayat (1) dihitung berdasarkan kerugian yang nyata-nyata dialami atau bagian biaya pelayanan maka dalam pengangkutan penumpang ganti kerugian dihitung berdasarkan kerugian yang nyata-nyata dialami atau bagian biaya perawatan. Dalam Pasal 192 ayat (5) ditentukan bahwa besarnya ganti kerugian lebih lanjut akan diatur dengan Peraturan Pemerintah. ${ }^{24}$

Perlu dibuat suatu standarisasi pelaksanaan operasi bus dalam rangka memberikan pelayanan yang terbaik dan seragam kepada masyarakat pengguna jasa bus transjakarta. Standarisasi pelaksanaan operasi bus dibuat dengan memperhatikan kaidah-kaidah manajemen transportasi publik yang baik, dan dirancang agar pengoperasian bus transjakarta dapat memberikan pelayanan yang nyaman, aman dan tepat waktu, kepada masyarakat penggunanya. Standar Prosedur Operasi ini ditetapkan oleh Badan Layanan Umum Transjakarta Busway dan Operator Bus Transjakarta diwajibkan untuk melaksanakan dan mematuhi Standar Prosedur Operasi ini. Badan Layanan Umum secara berkala melaksanakan evaluasi terhadap Operator Bus atas pelaksanaannya. Standar Prosedur Operasi Pelayanan ini terdiri atas standarisasi terhadap: kondisi bus; pengoperasian bus; keselamatan; pelayanan pelanggan; dan pelaporan.

Persyaratan umumnya adalah dalam pelaksanaan operasional transjakarta busway, Operator Bus berkewajiban untuk memberikan pelayanan yang sebaik-baiknya setingkat dengan pelayanan standar dunia kepada pengguna jasa transjakarta busway sehingga seluruh pengguna jasa dapat terlayani dengan baik. Pelayanan yang diberikan oleh Operator bus mencakup standar pelayanan dunia transportasi untuk pelayanan umum (public service) yang mencakup ketepatan waktu, kenyamanan, keselamatan, dan kehandalan. Bus yang dioperasikan oleh Operator Bus sebelum berangkat beroperasi dan selama beroperasi diwajibkan untuk memenuhi persyaratan-persyaratan sebagai berikut. Bus

23 Ibid, hlm. 105-106

24 Ibid, hlm. 97. 
dalam kondisi bersih dan laik pandang baik bagian luar dan bagian dalam. Bus telah menjalani perawatan berkala dengan semestinya dan tidak melewati batasan perawatan yang wajar sesuai dengan standar ATPM dan Standar Prosedur Operasi Perawatan. Dalam rangka menjaga keselamatan Penumpang pengguna jasa transjakarta busway, Operator bus wajib untuk mematuhi peraturan-peraturan.

Sebagaimana telah dijelaskan bus transjakarta atau yang sering disebut Transjakarta busway adalah angkutan massal cepat dengan menggunakan moda bus dengan kapasitas penumpang 30 orang duduk dan 50 orang berdiri, selain itu busway juga di fasilitasi dengan jalur, armada bus dan infrastruktur yang dibangun khusus. Di Daerah Khusus Ibukota Jakarta Transjakarta Busway termasuk ke dalam Pola Transportasi Makro (PTM) sebagai perencanaan umum pengembangan sistem transportasi di wilayah DKI Jakarta yang ditetapkan melalui Peraturan Gubernur Nomor 103 Tahun 2007 tentang Pola Transportasi Makro, dengan maksud untuk meningkatkan pelayanan dan penyediaan jasa transportasi yang aman, terpadu, tertib, lancar, nyaman, ekonomis, efisien, efektif, dan terjangkau oleh masyarakat. Disamping itu juga Pola Transportasi Makro bertujuan untuk menetapkan rencana induk sistem jaringan transportasi di Provinsi DKI Jakarta sebagai perwujudan tatanan transportasi wilayah.

Berdasarkan Peraturan Gubernur Nomor 103 Tahun 2007 tentang Pola Transportasi Makro, Transjakarta Busway dikategorikan kedalam angkutan umum massal. Angkutan umum massal maksudnya adalah angkutan umum dengan karakteristik pelayanan cepat dan berkapasitas tinggi. ${ }^{25}$ Dalam Pasal 1 angka 10 UULAJ yang menyebutkan bahwa kendaraan bermotor umum adalah kendaraan yang digunakan untuk angkutan barang dan/atau orang dengan dipungut bayaran. Berdasarkan pengertian kendaraan bermotor umum tersebut dapat dijelaskan bahwa Bus Transjakarta termasuk dalam kategori kendaraan bermotor umum karena setiap penum- pang bus Transjakarta dipungut bayaran melalui tiket dan bus Transjakarta tergolong dalam pengangkutan orang dan bukan pengangkutan barang.

BLU Transjakarta sebagai lembaga struktural yang mendapatkan kewenangan dari Dinas Perhubungan Provinsi Daerah Khusus Ibukota Jakarta untuk mengelola dan menyediakan jasa angkutan umum bus Transjakarta yang mempunyai kegiatan utama untuk memberikan pelayanan kepada masyarakat pengguna bus Transjakarta. Oleh sebab itu ditetapkan dalam Peraturan Gubernur Provinsi Daerah Khusus Ibukota Jakarta Nomor 48 Tahun 2006 tentang Pembentukan, Organisasi dan Tata Kerja Badan Layanan Umum Transjakarta Busway. Dengan dibentuknya Peraturan Gubernur tersebut bertujuan untuk menentukan tugas dan fungsi dari BLU Transjakarta Busway, yang salah satu tugas dan fungsinya adalah mengelola angkutan umum busway dan penyusunan serta pengendalian standar pelayanan operasional/standar pelayanan minimal angkutan umum busway. Dalam menjalankan fungsi dan tugasnya tersebut maka BLU Transjakarta Busway wajib membuat dasar acuan untuk menjalankan dan/atau mengoperasikan angkutan umum busway yang disebut dengan Standar Prosedur Operasi Pelayanan dan Pengoperasian Bus yang tujuannya adalah untuk terwujudnya pelayanan yang aman, nyaman, tertib, efektif serta efisien kepada masyarakat pengguna Transjakarta Busway.

Standar Prosedur Operasi Pelayanan tersebut ditetapkan oleh Badan Layanan Umum Transjakarta Busway dan Operator bus diwajibkan untuk melaksanakan serta mematuhi Standar Prosedur Operasi ini. Apabila operator bus melanggar ketentuan yang terdapat dalam standar prosedur operasi maka akan diberikan sanksi sesuai yang telah ditetapkan dalam standar prosedur operasi tersebut.

Setiap penyelenggaraan pengangkutan pasti mempunyai peluang untuk mendapatkan masalah atau kecelakaan. Besar kecilnya masalah yang timbul tidak terlepas dari peran peng-

25 Peraturan Gubernur Provinsi Daerah Khusus Ibukota Jakarta Nomor 103 Tahun 2007 tentang Pola Transportasi Makro, Pasal 1 angka 7. 
angkut dalam menjalankan angkutannya. Berdasarkan hal tersebut timbul suatu kewajiban atau tanggung jawab dari pengangkut untuk memberikan ganti rugi kepada pihak yang dirugikan. Dikarenakan bus Transjakarta berkaitan dengan pengguna jasa dan pihak ketiga, jika terjadi kerugian yang menimpa pihak ketiga dalam pelaksanaan angkutan umum busway maka pengaturan tanggung jawab BLU Transjakarta Busway terhadap pihak ketiga mengacu kepada ketentuan Pasal 194 ayat (1). Pasal 194 ayat (1) UULAJ menyebutkan bahwa perusahaan angkutan umum tidak bertanggung jawab atas kerugian yang diderita pihak ketiga, kecuali jika pihak ketiga dapat membuktikan bahwa kerugian tersebut disebabkan oleh kesalahan perusahaan angkutan umum. Berdasarkan ketentuan tersebut maka apabila pihak ketiga ingin menuntut ganti kerugian, pihak ketigalah yang harus membuktikan adanya kesalahan dari perusahaan angkutan, tuntutan tersebut didasarkan atas dasar perbuatan melawan hukum atau atas dasar kesalahan yang diatur dalam Pasal 1365 Kitab UndangUndang Hukum Perdata yang menyatakan bahwa setiap perbuatan melawan hukum yang merugikan orang lain, mewajibkan orang yang membawa kerugian tersebut mengganti kerugian. Berdasarkan Pasal 194 ayat (1) UULAJ maka Prinsip tanggung jawab terhadap pihak ketiga yang dianut adalah prinsip based on fault (berdasarkan atas kesalahan), karena antara pihak ketiga dengan perusahaan angkutan tidak terdapat perjanjian pengangkutan, akan tetapi tetap terdapat perikatan. Jadi pihak ketiga tidak dapat menuntut atas dasar sistem presumption of liability, karena tuntutan berdasarkan sistem presumption of liability hanya dapat dilakukan jika ada perjanjian pengangkutan.

Walaupun Perusahaan Angkutan umum tidak bertanggung jawab terhadap kerugian pihak ketiga seperti yang disebutkan dalam Pasal 194 ayat (1) UULAJ 2009, akan tetapi berdasarkan Pasal 235 ayat 2 (dua) yang menyebutkan bahwa jika terjadi cidera terhadap badan atau kesehatan korban akibat kecelakaan lalu lintas sebagaimana dimaksud dalam Pasal 229 ayat (1) huruf $b$ dan huruf $c$, pengemudi, pemilik kendaraan bermotor, dan/atau perusahaan angkut- an umum wajib memberikan bantuan kepada korban berupa biaya pengobatan dengan tidak menggugurkan perkara pidana. Maksud huruf $b$ dan c adalah merupakan pelanggaran kecelakaan lalu lintas ringan dan kecelakaan lalu lintas berat. Dalam standar prosedur operasi juga di disebutkan bahwa operator bus wajib memberikan bantuan kemanusiaan terhadap korban kecelakaan berupa: korban luka-luka diberikan biayan pengobatan; dan untuk korban yang meninggal dunia diberikan biaya pemakaman.

BLU Transjakarta mempunyai peraturan tersendiri yang di atur dalam Standar Prosedur Operasional bus sehingga Tanggung jawab Badan Layanan Umum Transjakarta terhadap pihak ketiga dalam hal terjadi kecelakaan didasarkan pada ketentuan yang terdapat dalam standar prosedur operasi yaitu hanya pada penanganan pertama pada kecelakaan dan tanggung jawab selanjutnya diserahkan kepada operator bus. Penanganan Kecelakaan yang di lakukan oleh BLU Transjakarta adalah sebagai berikut. Pertama, BLU Transjakarta Busway hanya membantu proses penanganan pertama yaitu menolong korban dan membawa ke Rumah sakit; kedua, penumpang yang berada didalam Transjakarta busway tersebut dipindahkan ke bus yang lain; ketiga, jalurnya di jaga oleh petugas Transjakarta Busway; keempat, BLU menghubungi operator bus; kelima, koordinasi dengan Rumah Sakit; dan keenam, koordinasi dengan keluarga korban.

Selanjutnya tanggung jawab diserahkan kepada operator bus selaku pihak yang ditugaskan oleh BLU Transjakarta untuk mengoperasikan bus karena operator bus bertanggung jawab penuh kepada BLU Transjakarta. Adapun standar prosedur operasi penanganan kecelakaan di dalam standar prosedur operasi sebagai berikut. Untuk kecelakaan yang berakibat pada terluka/ meninggalnya pihak ketiga, maka penangananny adalah sebagai berikut. Pertama, penanganan kecelakaan mengacu kepada prosedur penyidikan perkara kecelakaan resmi Kepolisian Republik Indonesia; kedua, pada saat terjadi kecelakaan, bus yang bersangkutan wajib berhenti, kecuali dalam keadaan memaksa untuk keselamatan; ketiga, pada saat terjadi kecelakaan, pramudi bus yang bersangkutan wajib untuk segera me- 
laporkan kecelakaan kepada pusat kendali Operator Bus dan petugas Badan Layanan Umum yang berwenang; dan keempat, setelah Bus Operator tersebut berhenti, pramudi wajib untuk bekerja sama dengan satuan pengamanan di bus dan petugas lainnya yang berwenang untuk: (a) memeriksa kondisi korban; (b) membuat laporan Kecelakaan; (c) melaporkan data terinci mengenai korban Kecelakaan kepada BLU Transjakarta Busway dalam waktu selambat-lambatnya $1 \times 12$ jam (satu kali dua belas jam), mencakup: nama lengkap, jenis kelamin, alamat, noomor telepon/e-mail, nomor telepon/e-mail kerabat terdekat/yang dapat dihubungi, jenis kecelakaan, deskripsi lengkap kejadian kecelakaan, dan deskripsi lengkap kondisi korban kecelakaan; (d) mengikuti prosedur hukum yang berlaku.

Tanggung jawab pengemudi Bus Transjakarta terhadap pihak ketiga yang diatur dalam standar prosedur operasi tidak dijelaskan secara rinci mengenai tanggung jawab pengemudi bus Transjakarta apabila bus kecelakaan dalam koridor dan mengakibatkan korban terluka atau meninggal. Hanya disebutkan korban saja dan tidak dijelaskan korban tersebut penumpang atau pihak ketiga. Setiap pelanggaran yang dilakukan akan diberikan sanksi, baik sanksi berupa sanksi administratif, indisipliner, maupun pemecatan terhadap aparatnya yang bertanggungjawab. Sanksi tersebut ditetapkan oleh BLU Transjakarta kepada Operator bus dan Operator bus yang berkewajiban memberikan sanksi kepada pengemudi. Berdasarkan pelanggaran yang dilakukan oleh pengemudi adalah tergolong pelanggaran berat maka sanksinya adalah bus dikeluarkan dari jalur Transjakarta Busway dan kilometer tempuhnya pada hari itu diperhitungkan 50\% dari kilometer yang sudah dicapai.

Ada beberapa jenis pelanggaran yang di atur dalam Standar Prosedur Operasional. Perta$m a$, pelanggaran ringan yaitu pelanggaran terhadap Standar Prosedur Operasi yang dilakukan oleh pramudi yang dikenakan sanksi administratif berupa surat teguran; kedua, pelanggaran sedang yaitu pelanggaran terhadap Standar Prosedur Operasi yang dilakukan oleh pramudi yang dikenakan sanksi administratif berupa pembebas tugasan sementara/skorsing; dan ketiga, pelanggaran berat adalah pelanggaran terhadap Standar Prosedur Operasi yang dilakukan oleh pramudi yang dikenakan sanksi pemberhentian dengan tidak hormat/pemecatan.

Tanggung jawab pengemudi juga diatur dalam ketentuan UULAJ. Misalnya seorang pengemudi karena kelalaiannya menabrak pengendara sepeda motor yang menyebabkan korban terluka ataupun meninggal maka pengangkutlah yang bertanggung jawab secara perdata atas tuntutan ganti rugi yang diajukan oleh korban (pihak ketiga) atau ahli warisnya. Seperti yang diatur dalam Pasal 191 UULAJ 2009 yang menyebutkan bahwa perusahaan angkutan umum bertanggung jawab atas kerugian yang diakibatkan oleh segala perbuatan orang yang dipekerjakan dalam kegiatan penyelenggaraan angkutan. Ketentuan ini sama dengan ketentuan umum yang terdapat dalam Pasal 1367 ayat (1) KUH Perdata yang menyebutkan bahwa seseorang tidak hanya bertanggung jawab terhadap kerugian yang disebabkan perbuatan sendiri tetapi juga untuk kerugian yang disebabkan perbuatan orang-orang yang menjadi tanggungannya, atau disebabkan oleh barang-barang yang berada dibawah pengawasannya. Untuk angkutan dijalan, maka yang diberlakukan adalah Pasal 191, karena berlaku adagium lex specialis derogate lex generalis yaitu ketentuan yang khusus menyampingkan ketentuan yang bersifat umum.

Baik dalam ketentuan Pasal 191 maupun Pasal 1367 ayat (1) KUH Perdata, menegaskan bahwa perusahaan angkutan umum bertanggung jawab secara perdata untuk memberikan ganti kerugian kepada penumpang, pengirim barang maupun terhadap pihak ketiga yang diakibatkan oleh segala perbuatan orang yang dipekerjakannya dalam kegiatan penyelenggaraan angkutan. Orang yang dipekerjakannya disini adalah awak kendaraan, seperti pengemudi, pengemudi cadangan, kondektur dan pembantu pengemudi. ${ }^{26}$

Berdasar penjelasan di atas terhadap pengemudi hanya dapat dikenakan tuntutan secara pidana karena menyebabkan luka atau mening-

26 Ibid. 
galnya seseorang. Pengemudi tidak dapat di tuntut secara perdata, karena secara tegas sudah diatur dalam ketentuan umum pada Pasal 1367 ayat (1) KUHPerdata maupun dalam ketentuan khusus pada Pasal 191 UULAJ Tahun 2009. Hal ini juga disebabkan karena sifat hubungan hukum antara perusahaan angkutan umum dengan supirnya adalah bersifat perjanjian perburuhan yang menimbulkan hubungan hukum atas dan bawah, tidak sejajar dan bersifat perjanjian pemberian kuasa tanpa upah. Tanpa upah karena upahnya di dalam perjanjian perburuhan.

BLU Transjakarta merupakan Perusahaan Angkutan Umum yang menyediakan jasa angkutan umum, oleh karena itu tanggung jawab Perusahaan Angkutan Umum terhadap Pihak ketiga diatur dalam Pasal 194 ayat (1) UULAJ yang menyebutkan bahwa perusahaan angkutan umum tidak bertanggung jawab atas kerugian yang di derita pihak ketiga, kecuali jika pihak ketiga dapat membuktikan bahwa kerugian tersebut disebabkan oleh kesalahan perusahaan angkutan umum. Berdasarkan ketentuan tersebut maka apabila pihak ketiga ingin menuntut ganti kerugian, pihak ketigalah yang harus membuktikan adanya kesalahan dari perusahaan angkutan. Akan tetapi berdasarkan Standar Prosedur Operasi tidak dilihat pihak mana yang bersalah dalam hal terjadi kecelakaan, karena di dalam Standar Prosedur operasi penanganan kecelakaan untuk kecelakaan yang berakibat pada terlu$\mathrm{ka} /$ meninggalnya pihak ketiga hanya dijelaskan bahwa operator bus wajib memberikan bantuan kemanusiaan kepada korban kecelakaan sebagai berikut: luka-luka: biaya pengobatan; dan meninggal dunia: biaya pemakaman. ${ }^{27}$ Selain biayabiaya tersebut di atas, hak-hak korban berdasarkan Undang-undang Nomor 33 dan 34 Tahun 1964 tentang Asuransi Kecelakaan menjadi hak korban/ahli waris.

\section{Penutup}

Simpulan

27 Hal-hal seperti ini akan lebih baik diselesaikan secara musyawarah mufakat, daripada diputuskan melalui pengadilan yang berbelit dan lama. Baca dan bandingkan dengan artikel Adi Sulistiyono, "Budaya Musyawarah un-
Setiap penyelenggaraan pengangkutan pasti mempunyai peluang untuk mendapatkan masalah atau kecelakaan. Besar kecilnya masalah yang timbul tidak terlepas dari peran pengangkut dalam menjalankan angkutannya. Berdasarkan hal tersebut timbul suatu kewajiban atau tanggung jawab dari pengangkut untuk memberikan ganti rugi kepada pihak yang dirugikan, dikarenakan bus Transjakarta berkaitan dengan pengguna jasa dan pihak ketiga, jika terjadi kerugian yang menimpa pihak ketiga dalam pelaksanaan angkutan umum busway maka pengaturan tanggung jawab Badan Layanan Umum Transjakarta Busway terhadap pihak ketiga mengacu kepada ketentuan Undang-Undang Lalu Lintas dan Angkutan Jalan sebagaimana yang terdapat didalam Pasal 194 ayat (1). Pasal 194 ayat (1) UULAJ menyebutkan bahwa perusahaan angkutan umum tidak bertanggung jawab atas kerugian yang diderita pihak ketiga, kecuali jika pihak ketiga dapat membuktikan bahwa kerugian tersebut disebabkan oleh kesalahan perusahaan angkutan umum.

Berdasarkan ketentuan tersebut maka apabila pihak ketiga ingin menuntut ganti kerugian, pihak ketigalah yang harus membuktikan adanya kesalahan dari perusahaan angkutan, tuntutan tersebut didasarkan atas dasar perbuatan melawan hukum atau atas dasar kesalahan yang diatur dalam Pasal 1365 Kitab UndangUndang Hukum Perdata yang menyatakan bahwa setiap perbuatan melawan hukum yang merugikan orang lain, mewajibkan orang yang membawa kerugian tersebut mengganti kerugian.

Berdasarkan Pasal 194 ayat (1) UULAJ maka Prinsip tanggung jawab terhadap pihak ketiga yang dianut adalah prinsip based on fault (berdasarkan atas kesalahan), karena antara pihak ketiga dengan perusahaan angkutan tidak terdapat perjanjian pengangkutan, akan tetapi tetap terdapat perikatan. Jadi pihak ketiga tidak dapat menuntut atas dasar sistem presumption of liability, karena tuntutan berdasarkan sistem

tuk Penyelesaian Sengketa Win-Win Solution dalam Perspektif Hukum", Jurnal Hukum Bisnis, Volume 25 No. 1. 2006, Jakarta. 
presumption of liability hanya dapat dilakukan jika ada perjanjian pengangkutan.

Walaupun Perusahaan Angkutan umum tidak bertanggung jawab terhadap kerugian pihak ketiga seperti yang disebutkan dalam Pasal 194 ayat (1) UULAJ 2009, akan tetapi berdasarkan Pasal 235 ayat 2 (dua) yang menyebutkan bahwa jika terjadi cidera terhadap badan atau kesehatan korban akibat kecelakaan lalu lintas sebagaimana dimaksud dalam Pasal 229 ayat (1) huruf $b$ dan huruf $c$, pengemudi, pemilik kendaraan bermotor, dan/atau perusahaan angkutan umum wajib memberikan bantuan kepada korban berupa biaya pengobatan dengan tidak menggugurkan perkara pidana, yang di maksud dengan huruf $\mathrm{b}$ dan $\mathrm{c}$ adalah merupakan pelanggaran kecelakaan lalu lintas ringan dan kecelakaan lalu lintas berat.

\section{Daftar Pustaka}

Gultom, Elfrida. 2008. Hukum Pengangkutan Darat. Jakarta: PT. Literata Lintas Media;

Khairandy, Ridwan. "Tanggung Jawab Pengangkut dan Asuransi Tanggung Jawab Sebagai Instrumen Perlindungan Konsumen Angkutan Udara". Jurnal Hukum Bisnis, Vol 25, 2006, Jakarta;

Mahardika, Ida Bagus Bayu dan I Ketut Sandhi Sudarsana. "Perbuatan Melanggar Hukum oleh Maskapai Penerbangan Terkait Pembatalan dan Keterlambatan Pengangkutan”. Jurnal Kertha Semaya, Vol. 02 No. 1 Februari 2014, Denpasar: FH Univ. Udayana;

Muazzin. "Tanggung Jawab Pangangkut Udara Terhadap Kerugian Penumpang dan Pihak Keti-ga di Permukaan Bumi". Jurnal Kanun, No. 29 Edisi Agus-tus 2001, Banda Aceh: FH Univ. Syiah Kuala;

Muhammad, Abdulkadir. 1991. Hukum Pengangkutan Darat, Laut dan Udara, Bandung: PT. Citra Aditya Bakti;

Nugraha, I G A Wahyu. Nyoman A. Martana, "Perlindungan Hukum terhadap Penumpang Tanpa Tiket (Illegal) dalam Pengangkutan Darat di Indonesia". Jurnal Kertha Semaya, Vol. 02, No. 01, Februari 2014. Denpasar: FH Universitas Udayana;

Putra, Darmadi Charisma. I Ketut Markeling, I Made Dedy Priyanto. "Perlindungan Hukum terhadap Pihak Tertanggung dalam
Asuransi Demam Berdarah pada Pt. Asuransi Central Asia", Jurnal Kertha Semaya, Vol. 02, No. 04, Juni 2014. Denpasar: FH Universitas Udayana;

Sulistiyono, Adi. "Budaya Musyawarah untuk Penyelesaian Sengketa Win-Win Solution dalam Perspektif Hukum". Jurnal Hukum Bisnis, Volume 25 No. 1. 2006, Jakarta;

Sunarmi. "Pemegang Polis Asuransi dan Kedudukan Hukumnya". Jurnal Ilmu Hukum, Vol. 3 No. 1 2012, Pekanbaru: FH Univ. Riau;

Wiradipradja, E. Saefullah. "Tanggung Jawab Perusahaan Penerbangan Terhadap Penumpang Menurut Hukum Udara Indonesia”, Jurnal Hukum Bisnis, Vol 25. 2006, Jakarta;

Yulianto, Taufiq. "Mekanisme Pengangkutan Barang Melalui Laut Ditinjau dari Sudut Hukum Pengangkutan”. Orbith, Vol. 9 No. 3 November 2013. 